\title{
КЛЮЧОВІ ТЕНДЕНЦІї ПІДГОТОВКИ ДО БОЙОВИХ ПОЛЬОТІВ МАЙБУТНІХ ВІЙСЬКОВИХ ЛЬОТЧИКІВ В СУЧАСНИХ УКРАЇНСЬКИХ РЕАЛІЯХ
}

\author{
Невзоров Р. В., кандидат педагогічних наук, начальник кафедри тактики авіачії, Харківський \\ національний університет Повітряних Сил імені Івана Кожедуба, м. Харків, Украӥна \\ DOI: https://doi.org/10.31435/rsglobal_conf/25112020/7255
}

\begin{abstract}
The article is sanctified to the tendencies of preparation to battle flights of future soldiery pilots in Ukraine. A six-year-old military threat in Ukraine stipulates updating and modernisation of maintenance, methodology and all scientific vehicle of the home system of the professional training of soldiery personnels of higher qualification. Especially it touches preparation to battle flights, as basic professional activity, students of higher military establishment of formation of aviation direction. During many years this system remains, essentially, laid-up, practically unchanging, taking into account the technical backwardness of military aviation park of Aircrafts of the Armed Forces of Ukraine and formal going near regulation of process. On the basis of selection and primary analysis of key tendencies of the indicated preparation an author comes to the appropriate conclusion about the necessity of development of the modern in-applied pedagogical system of preparation to battle flights.
\end{abstract}

Keywords: cadets-military pilots, battle flight, professional preparation, higher military establishment of education, quality of professional preparation, tendency.

Вступ. Загострення й ескалація геополітичних протиріч у Східній Європі в XXI ст. зі сторони одного з суб'єктів міжнародної політики даного регіону призвели до того, що Україна вже шість років перебуває в стані неоголошеного військового конфлікту, а іï територіальна цілісність грубо порушена ззовні. Вказаний конфлікт за змістом військові фахівці відносять до новітнього різновиду воєн - так званих «гібридних». Останні відрізняються тим, що орієнтовані не на відкриту військову агресію і класичне воєнне протистояння, а на скриті диверсійні операції та різнобічну підтримку «п’ятої колони» в середині країни-противника; війна ведеться не лише на фронтах бойових дій, а й в інформаційному та кіберпросторі. Теорія контрстратегії гібридним війнам ще формується, але вже зараз очевидно, що ії обов'язковим елементом $є$ оновлена система фахової підготовки військових кадрів загалом і військових льотчиків зокрема.

Сучасний військовий пілот повинен бути психологічно, фізично і практично здатний виконати поставлені бойові завдання різної складності в різноманітних умовах ведення бою на складних літальних апаратах. Особливо це стосується льотчиків тактичної авіації, на яку покладена місія завоювати перевагу в повітрі і забезпечити стратегічне військове домінування.

Оскільки в Україні фахова підготовка військових пілотів ведеться нерозривно із здобуттям ними вищої військової освіти, вона відбувається у вищих військових закладах освіти (ВВ3О), а майбутні військово-авіаційні кадри виступають в статусі курсантів. Отже, наукова проблема підготовки до бойових польотів майбутніх військових льотчиків є передусім педагогічною проблемою, що знаходиться на межі таких суміжних наукових дисциплін як професійна педагогіка, авіаційна педагогіка і психологія, але найбільше тяжіє до військової педагогіки.

Аналіз підготовки майбутніх пілотів тактичної авіації до бойових польотів у ЗВВО, як предмету військово-педагогічного дослідження, доцільно починати 3 вивчення основних тенденцій, виокремлення яких сприятиме кращому розумінню слабких сторін існуючої педагогічної системи.

Науково-теоретичним підгрунтям даного дослідження є праці вітчизняних і зарубіжних науковців з вище вказаних наукових дисциплін, зокрема: Д. Гандера, Н. Завалової, Б. Ломова, В. Маріщук, К. Платонова, Б. Покровського, В. Пономаренко (психологічні особливості льотної праці та діяльності); П. Картамишева, О. Керницького, П. Корчемного, Р. Макарова, Т. Плачинди, П. Онипченко, О. Тарасова (окремі особливості професійної підготовки військових льотчиків) та інших. Педагогічні праці з близьких проблем представлені Т. Джамгаровим, Є. Мілеряном, В. Небиліциним, Б. Тепловим, В. Трошиним (професійний відбір льотчиків); О. Деминським, Є. Клімовим (формування професійної придатності); В. Бондаренком, В. Юсовим (розвиток професійного мислення військових пілотів) та деякими іншими.

Метою даної статті є виокремлення та початковий аналіз ключових тенденцій підготовки до бойових польотів майбутніх військових льотчиків в ЗВВО України на сучасному етапі. 
Методи дослідження. Вибір наукових підходів пізнання предмету дослідження обумовлений рядом суттєвих чинників:

- по-перше, фахова підготовка військових льотчиків як кадрових офіцерів Повітряних Сил Збройних Сил України (ПС ЗСУ) на сьогодні здійснюється в одному вітчизняному ВВЗО Харківському національному університеті Повітряних Сил імені Івана Кожедуба, що значно звужує базу вивчення відповідного досвіду;

- по-друге, частина інформації, пов'язаної з даною проблемою, є вузько обмеженою, стосується національної безпеки і оборони і не може бути включена до цивільного військовопедагогічного дослідження, що також звужує і обмежує предметну базу;

- по-трете, підготовка до бойових польотів майбутніх військових льотчиків в ЗВВО України як самостійний педагогічний конструкт досі ще не розглядалася в українській науці, тому безпосередні науково-теоретичні джерела з цього питання просто відсутні.

Саме тому, методологічну базу нашого дослідження склали дві групи методів:

- теоретичні аналіз і синтез наукової літератури;

- емпіричні методи аналізу документів (керівні організаційні та методично орієнтуючі документи) та педагогічного спостереження (за методикою викладачів та інструкторів Харківського національного університету Повітряних Сил імені Івана Кожедуба).

Також, був здійснений аналіз авторського досвіду роботи у ВВЗО з підготовки військових пілотів.

Результати дослідження. В своєму дослідженні ми виходимо з базової установки, відповідно до якої підготовка до бойових польотів майбутніх військових льотчиків $€$ центральною складовою (підсистемою) якісної фахової підготовки у ВВЗО. В рамках авторської докторської дисертаційної роботи ми пропонуємо розглядати:

- фахову підготовку майбутніх військових льотчиків як комплекс спеціальних, спеціально-тактичних навчальних дисциплін і курсів, а також спеціалізованого тренажерного, фізичного та фізіологічного навчання, що складає базовий компонент професійної підготовки військових пілотів у ЗВВО і спрямований на формування у них спеціальних військових льотних компетенцій та фахової готовності до виконання бойових завдань [1];

- якість фахової підготовки майбутніх льотчиків тактичної авіації як інтегрований показник відповідності набутих ними професійних компетенцій, фахово значимих вмінь та навичок, а також реальної готовності до виконання бойових задач відносно конкретних вимог Повітряних Сил ЗСУ, запитів та очікувань суспільства до сучасних кадрових офіцерів-льотчиків [2].

Це найважливіша за значенням іiі частина, так як основна професійна діяльність військових пілотів за призначенням - бойові польоти (бойові чергування, патрулювання, супроводження, повітряні бої тощо). Здатність ефективно виконувати поставлені бойові завдання льотчик формує в процесі якісної фахової підготовки до бойових польотів.

Категорію «бойовий політ», що запозичена військовою педагогікою з військових наук, ми розуміємо стосовно основної проблеми нашого дослідження як основний вид професійної діяльності військових льотчиків, спрямований на виконання бойової задачі, а готовність до нього (фізична, психологічна, технічна) - як ключовий компетентнісний індикатор педагогічної системи забезпечення якості підготовки майбутніх льотчиків тактичної авіації до виконання бойових завдань (законодавчо бойові польоти в Україні визначаються як польоти на виконання бойового завдання (завдання за призначенням) [3]).

Найсуттєвішими сучасними українськими реаліями, що впливають на вимоги і зміст до підготовки до бойових польотів майбутніх військових льотчиків, $є$ перманентна військова загроза і необхідність військового потенціалу, здатного їй протистояти та об'єктивні підвищені вимоги до військових пілотів, що пов'язані з глобальним військово-технічним прогресом і розвитком військово-авіаційної тактики. Вони виступають соціальним тлом, в межах якого формується державне оборонне замовлення і замовлення на підготовку військових кадрів вищої кваліфікації, а також їх громадська легітимізація.

Чинна Освітньо-професійна програма «Льотна експлуатація та бойове застосування літаків» першого (бакалаврського) рівня вищої освіти за спеціальністю 253 «Військове управління (за видами Збройних Сил)», галуззю знань 25 Воєнні науки, національна безпека, безпека державного кордону, спеціалізацією Льотна експлуатація та бойове застосування літаків, розроблена і затверджена Вченою радою Харківського національного університету Повітряних Сил імені Івана Кожедуба (протокол № 5 від 26.06.2019 р.) на основі стандарту вищої освіти за спеціальністю 253 «Військове управління (за видами Збройних Сил)», затвердженого наказом Міністерства освіти і науки України (МОНУ) № 1168 від 29.10.2018 р. та Методичних 
рекомендацій щодо розроблення стандартів вищої освіти, затверджених наказом МОНУ № 600 від 01.06.2017 р. (у редакції наказу № 1648 від 21.12.2017 р.) мала б враховувати ці реалії. Натомість, авторський контент-аналіз переліку компетенцій чинної ОПВО 2019 р. зі змістом умінь i навичок освітньо-кваліфікаційної характеристики (як компоненту ГСВО) цієї ж спеціальності і спеціалізації попереднього Галузевого стандарту вищої освіти 2013 р. засвідчив співпадіння між ними в цілому за змістом на $86,4 \%$, в цілому за формулюванням - на 55,6\%. Формалізований, описовий, нетенденційний зміст даного документу не дає жодного уявлення щодо особливостей змісту організації підготовки до бойових польотів у ВВЗО.

Більш наближений до практичної сфери підготовки військових льотчиків Курс наземної і льотної підготовки курсантів на бойовому літаку (КНБП БЛ-2017), затверджений наказом командувача Повітряних Сил Збройних Сил України від 26 квітня 2017 р. № 40, свідчить про подібне: документ хоч і носить системний характер, але суттєво не відрізняється від попередніх КНБП БЛ 2000-х pp. і навіть 1990-х рр., що вказує на його консервативний характер, тенденційність, значну невідповідність сучасному технічному рівню авіаційної техніки (напр., Су-25 та Міг-29 традиційно відносять до четвертого покоління бойових літаків, тоді як потенційний противник - Росія - активно поповнює в останні роки свій авіапарк літаками покоління 4+ (Су-30, Су-33), 4++ (Су-35, МiГ-35), а з 2019 р. - і п'ятим поколінням бойових літаків (Су-57), що вимагає істотної зміни конфігурації підготовки до протидії і протистояння цим типам військово-авіаційних комплексів).

Вище зазначене вказує на те, що організаційно-керівні та методично орієнтуючі документи, що регламентують функціонування системи і визначають зміст фахової підготовки військових льотчиків, мають застарілий характер, не достатньо враховують реалії потенційної загрози військової агресії та рівень військово-авіаційної техніки агресора. Ця тенденція простежується на протязі всієї новітньої незалежної історії України в кін. XX - на поч. XXI ст.

Ще однією негативною ключовою тенденцією розвитку вітчизняних ПС ЗСУ є застарілість і часткова зношеність їх військового авіапарку. Чисельні профільні фахівці, думку яких вивчав автор, паралельно висловлюють скепсис у цьому питанні, пов'язаний з відсутністю нових та повільною модернізацією існуючих зразків військової авіаційної техніки, що не дозволяє сьогодні істотно змінити форми застосування авіації та привести до потреби удосконалення існуючих способів їх застосування за рахунок комплексування наявних сил і засобів, застосування нових тактичних прийомів, внесення змін до порядку планування, управління та всебічного забезпечення авіації. Подібні невтішні висновки зустрічаються і у деяких українських вчених [4].

Також, на думку автора, існуючі та практично незмінні впродовж багатьох років форми організації підготовки до бойових польотів в Україні тяжіють більше до радянської i пострадянської методики льотного навчання, ніж до сучасної педагогічної системи. Для них характерний тенденційний погляд на неї як на специфічний різновид «льотної справи» (популярна в радянській науці концепція др. пол. ХХ ст.); домінування психологічної складової підготовки над педагогічною; орієнтування методики підготовки на існуючий авіапарк.

Висновки. Таким чином, ключовими тенденціями підготовки до бойових польотів майбутніх військових льотчиків в сучасних українських реаліях є:

- iї технічне, методологічне та методичне відставання від передового світового досвіду;

- тенденційний та подекуди регресуючий характер її змісту, що не достатньо враховує вимоги глобального військово-технічного та військово-тактичного прогресу.

Значно поліпшити іiі теоретичне наповнення здатна окрема педагогічна система, побудована на новітній науково-теоретичній основі, з попередньо розробленою теоретичною моделлю та експериментальною перевіркою її працездатності і ефективності на базі ВВЗО.

\section{REFERENCES}

1. Невзоров Р.В. Наземне навчання бойовим польотам як умова якісної фахової підготовки майбутніх льотчиків тактичної авіації. Педагогічні науки: теорія, історія, інноваційні технології. 2020. №1 (95). С. 248-256.

2. Невзоров Р.В. Створення педагогічної системи забезпечення якості наземного навчання бойовим польотам майбутніх льотчиків тактичної авіації у контексті поступу України до НАТО: до постановки проблеми. Modernization of the education system: world trends and national peculiarities. Kaunas, Lithuania, 2020. P. 45-50.

3. Про затвердження Правил польотів державної авіації в повітряному просторі України: Наказ Міністерства оборони України від 9 грудня 2015 p. № 700. Електронний ресурс. URL: http://search.ligazakon.ua/1_doc2.nsf/link1/RE28067.html (дата звернення: 20.11.2020).

4. Артеменко А.М., Астахов О.О., Коваль В.В., Жарик О.М. Погляди щодо подальшого розвитку форм і способів застосування Повітряних Сил ЗС України в сучасних операціях (бойових діях). Наука і техніка Повітряних Сил Збройних Сил Украӥни. 2015. № 2(19). С. 6-9. 